\title{
World Poetry and Criticism As Reflected in Contemporary Arabic Poetry: Myth and Acculturation
}

\author{
Mahmud Naamneh \\ Academic College Achva \\ Saleem Abu Jaber \\ Academic College Achva
}

Contemporary Arab poets have been influence by ancient myths, which they used in their poems to convey various meanings. The poets were able to use these materials following their indirect exposure to their contents. ${ }^{1}$ Perhaps the most important channel through which they accessed this was the poetry of the American poet Thomas S. Eliot (1888-1965). The channels were the following:

\section{The first station: The poetry of T.S. Eliot}

Critics view T.S. Eliot as the spiritual father of modern Arabic poetry after World War II. ${ }^{2}$ Eliot, who pioneered the use of myth in poetry, stated that he had been influenced by Frazer's The Golden Bough. ${ }^{3}$ He used the materials of myth to forge new meanings fit for his age. In order to do this Eliot ${ }^{4}$ found it necessary to use the new techniques of parataxis and objective correlative, constructions that overstep the bounds of language in its ordinary usage and of myth in its traditional meaning. ${ }^{5}$

Among contemporary Arab poets the only one to have adopted a well-defined method for dealing with myths was Sa'dī Yūsuf, who used the technique of "complex model intertextuality", which, the present paper argues, is a modernist technique for the use of myths. In the opinion of the present author it was Eliot's theory of the objective correlative that drew the attention of contemporary Arab poets towards ancient mythology. In his theory, Eliot states that the aim of an artist is not merely to express ideas as such, or emotions as such, but rather to find the "objective correlative", a term which he invented and first used in his study of Shakepeare's play Hamlet, published in 1919. In that study Eliot argued that the only way to express feelings in a work of art was to discover an "objective correlative", by which he meant "a set of objects, a situation, a chain of events which shall be the formula of that particular

\footnotetext{
${ }^{1}$ See: Abū Sayf, 2005, 211. The expression "indirect exposure" refers to the fact that the myths were used in a way that did not fit the poetic content because poets' acquaintance with the myths was indirect, through the writings of Western poets, especially T.S. Eliot. A good example of this usage is provided by al-Sayyāb's early poetic writings, where he imitated the use of myths in Western poetry, not always in a way that was consistent with the meanings that he intended to convey.

2 Hallāwī, 1997, 7-9; al-Gharfī, 1987, 92-93.

${ }^{3}$ Eliot, 1963, 23.

4 Eliot and Ezra Pound are considered the spiritual fathers of modernism in American poetry; see M. Levenson, 1986 Pound, too, was influenced by myths and used them in his poetry; he believed that myths originated in the experiences of people in antiquity, who felt the need to hide from their persecutors. He thus did not view myths as tradition or a record of the past, but rather as heritage of the past that affects the future; see Shāhīn, $1996,43$.

5 Shāhīn, op.cit., 52.
} 
emotion; such that when the external facts, which must terminate in sensory experience, are given, the emotion is immediately evoked".

The objective correlative depends to a large extent on the poet's own cultural level and intelligence. Only a poet in whom culture and intelligence are stronger than emotion and poetship is capable of understanding life's problems and of expressing them in an appropriately poetic manner that combines rational logic with poetic affect. ${ }^{6}$ In other words, the objective correlative can be a myth from the past that expresses problems of the present.

A myth is "a situation, a chain of events", a well-known formulation, which when used in poetry perforce excites the reader through the new meaning that it expresses, such as commitment, emigration or the homeland. In this way the myth ceases to play the role of something found in the pages of history and becomes an objective correlative that expresses a new idea.

Eliot's idea of embracing antiquity was welcomed by contemporary Arab poets, who also believed that the past and the present complemented each other and that the past can provide rich materials with which to express the problems and complexes of the modern world. ${ }^{7}$

The Waste Land, in which Eliot uses various myths, influenced Western and Arab poets more than any other poem. ${ }^{8}$ In it Eliot expressed profound human truths. Modernist poets, Eliot among them, often used rain as a symbol for good, change and rebellion and drought and desolation as symbols for coercion and subjection. ${ }^{9}$ Subsequently Arab poets used the expression "waste land" to depict the state of subjection and oppression under which they suffered.

Eliot found in myth rich and unusual materials. His initial aim was not to transfer the myth from the past to the present, but to shape its cultural and literary contents so as to make it appropriate for the meanings of his times. ${ }^{10}$

Contemporary Arab poets, especially Sa'dī Yūsuf, found what they sought in The Waste Land, in which myths and adaptations abound. It is a poem that can represent the crisis of any land in the world, at any time in history. ${ }^{11}$ The Arab poets who were most influenced by Eliot were Badr Shākir al-Sayyāb and Sa'dī Yūsuf, both from Iraq. ${ }^{12}$ Both saw in the poem a most violent satire on capitalist society, of a kind that even the Communists could not produce, despite their contempt for capitalism. ${ }^{13}$

Following this survey let us examine some passages from The Waste Land and follow its mythical allusions:

\footnotetext{
6 idem, 1963, 30.

7 Eliot, ????, ???.

${ }^{8}$ Abū Sayf, 2005, 214-216; Hallāwī, 1997, 7-9. The following poets, among others, have made considerable use of myth: Khalīl al-Ḥāwī, Yūsuf al-Khāl, Adonis, Badr Shākir al-Sayyāb and Jabrā Ibrāhīm Jabrā.

${ }^{9}$ Khalīl, 2003, 332.

10 Shāhīn, 1996, 56-57; Moreh, 1976, 246-258.

11 See Eliot, ???, ???. Modern Arab poets turned to this work as a kind of consolation for the Arabs' sad state after World War II; see: Hallāwī, op. cit., 7-9, Moreh, op.cit., 247-248.

${ }^{12}$ According to Moreh, Eliot had a great deal of influence on Lebanese and Iraqi poets, especially the avant-garde poets of the Lebanese journal Shi'r; see: Moreh, op.cit., 253.

13 Eliot, 1963, 31; see also Mahmūd, 2003, 69-71.
} 


\section{The first passage:}

Huge sea-wood with copper

Burned green and orange, framed by the coloured stone,

In which sad light a carv'd dolphin swam.

Above the antique mantel was displayed

As though fed a window gave upon the sylvan scene

The change of Philomel, by the barbarous king

So rudely forced; yet there the nightingale

Filled all the desert with inviolable voice

And still she cried

Here Eliot alludes to the myth of Philomela the beautiful princess, who was summoned to the castle of her brother-in-law, who rapes her, imprisons her in a cabin and cuts off her tongue so that she would not tell what he had done to her. However, his wife discovered what had happened and killed his son in revenge. She boiled him and served him as a meal to her husband. She freed her sister Philomela, who was transformed into a nightingale. ${ }^{14}$

\section{The second passage:}

Damyata: The boat responded

Gaily, to the hand expert with sail and oar

The sea was calm, your heart would have responded

Gaily, when invited, beating obedient

To controlling hands ${ }^{15}$

The word "Damyata" in this passage means "Give!". It is taken from the myth of thunder in the Hindu Vedic literature, composed about 500 BCE. When the thunder god said this word all the other gods and men obeyed.16 In the poem it is the boat that responds to the command "gaily". The sailors prepared to set sail and return and the sea was calm. Apparently there is a person whom the poet hides here, someone who gladly takes part in this voyage and responds to the call "Damyata".

\section{The third passage:}

I Tiresias, though blind, throbbing between two lives,

Old man with wrinkled female breasts, can see

At the violet hour, the evening hour that strives

Homeward, and brings the sailor home from sea,

The typist home at teatime, clears her breakfast, lights

Her stove, and lays out food in tins.

Out of the window perilously spread

Her drying combinations touched by the sun's last rays,

On the divan are piled (at night her bed)

Stockings, slippers, camisoles, and stays.

I Tiresias, old man with wrinkled dugs

Perceived the scene, and foretold the rest-

I too awaited the expected guest.

\footnotetext{
14 Eliot, 1963, 32; 'Abd al-Hayy, 2008, 4.

15 see also: 'Abd al-Hayy, op.cit., 7.

16 Eliot, 1963, 33; 'Abd al-Hayy, op.cit., 7.
} 
He, the young man carbuncular, arrives,

A small house agent's clerk, with one bold stare,

One of the low on whom assurance sits

As a silk hat on a Bradford millionaire.

The time is now propitious, as he guesses,

The meal is ended, she is bored and tired,

Endeavours to engage her in caresses

Which still are unreproved, if undesired.

Flushed and decided, he assaults at once;

Exploring hands encounter no defence;

His vanity requires no response,

And makes a welcome of indifference.

And I Tiresias

In this passage we encounter the mythical Greek figure of Tiresias, a man who was blinded and transformed into a woman by Hera. To compensate him for the loss of his sight, Zeus made him clairvoyant. ${ }^{17}$ Here Eliot through Tiresias says that he lived his life as a blind man, alternating between two lives, one as an old man and the other as a person with female features and large breasts. Tiresias boasts that he can perceive the unseen during the evening hour, differentiate between times and identify things, such as the typist who cleans up the remains of breakfast in her home. He can describe the house without seeing it, including her clothesline outside her window that is brushed by the sun's rays, and the stockings and underware piled on her divan, that also served as her bed. Tiresias continues to speak about his life and his prophetic abilities. He expects the coming guest, a young house agent's clerk, minutely described by Tiresias. The young man exploits his opportunity to court the tired women just described. She does not respond to his advances, but he continues all the same.

\section{The fourth passage:}

Phlebas the Phoenician, a fortnight dead, Forgot the cry of gulls, and the deep sea swell

And the profit and loss.

A current under sea

Picked his bones in whispers. As he rose and fell

He passed the stages of his age and youth

Entering the whirlpool.

Gentile or Jew

0 you who turn the wheel and look to windward,

Consider Phlebas, who was once handsome and tall as you ${ }^{18}$

In this passage there is an allusion to the myth of Phlebas the Phoenician, which brings us back to ancient Canaan and the Phoenician kingdom that ruled what today is Lebanon. ${ }^{19}$

\footnotetext{
17 Eliot, 1963, 34; 'Abd al-Ḥayy, op.cit., 9.

18 'Abd al-Hayy, 2008, 11.

${ }^{19}$ Eliot and his theories greatly influenced modern Arab poets. For more information on this topic, which cannot be further discussed here, see Jeries Khouri's Ph.D. thesis, al-Mașādir al-sha 'biyya lil-shi'r al-'arabī al-ḥadīth, 2004.
} 


\section{The second station: The Lebanese journal Shi'r}

This journal and its cultural and literary project ${ }^{20}$ played a great role in making Arab poets aware of mythology. In fact, its theoreticians and critics frequently called for accepting ancient myths. The "Tammuz Movement" which founded the journal also played an important role in familiarizing modern Arab poets with mythical materials, especially after a return to myth became a qualitative ideological model in the history of Arab poetic discourse..$^{21}$ The ideas of this movement also influenced Anțūn Sacāda's book al-Sirāa al-fikrī fì al-adab al-sūrī (Intellectual Conflict in Syrian Literature; 1940). 22 Members of the Tammuz Movement discovered that some of the important figures in Greek traditions can be identified with the traditions of the Fertile Crescent; thus Aphrodite is Ishtar, and Adonis is Tammuz. ${ }^{23}$

Shi $r$ called on Arab poets directly and indirectly, through poetry, prose and essays, to take a unified view of accumulated human experience in the course of history. As an example of a direct address to writers on this issue we may take a study the journal published under the title "al-Ustūra fī al-shi'r al-'arabī al-mu'āșir" ("Myth in Contemporary Arabic Poetry"), ${ }^{24}$ in which the author, As'ad Razzūq, showed how frequently modern Arab poets made use of myth. According to the critic and poet Jabrā Ibrāhīm Jabrā, a poet who made use of myth, Arab poets began to use it towards the end of the 1940s and in the course of the 1950s, at the urging of Shi $r$. At that time their objective was to express the sad state of the Arabs, to draw attention to their plight and to make the world identify with them. The journal succeeded in taking myths out of the museums and inducing contemporary Arab poets to give them personal meanings. ${ }^{25}$

Contemporary Arab poets realized that mythology could be made to symbolize human struggle and resistance in the past and in the present, not merely as a form of psychological compensation for the frustrations and defeats experienced by Arabs and for their failure to realize their aspirations in the real world; but that in fact they provide solutions to crises and can help in the search for new approaches through which Arabs can extricate themselves from their personal, social and national problems. ${ }^{26}$ In this way Shi'r paved the way for Sa'dī Yūsuf and other Arab poets to adopt Mesopotamian mythology and to use it in their works.

\section{The third station: James Frazer and The Golden Bough}

The modern approach to the study of myth emerged in the nineteenth century with the works of the orientalist and linguist Max Müller (1823-1900), who classified myths according to their purpose. He was followed by the Scottish social anthropologist James Frazer (1854-1941), who associated mythology with the idea of fertility in nature, ${ }^{27}$ a thesis that he pursued in his book The Golden Bough, published in ten volumes between 1890 and 1915.28

Arab intellectuals who wished to free themselves of the bonds of religion in the Arab and Muslim worlds found in Frazer's studies arguments that legitimized their rebellion against it.

\footnotetext{
${ }^{20}$ For more on this journal's pioneering role in Arab literary modernism and its contributions to making the myths of antiquity accessible see Būwārdī 2003; Būwārdī 1998.

${ }^{21}$ Al-Sham'a, 2002, 74.

22 See Sa‘̄āda, 1940.

${ }^{23}$ Al-Sham'a, 2000, 74; see Lu’lu’a, 1980, 49-50. For more on the influence of Phoenician mythology on Iraqi and Lebanese poets see: Moreh, op.cit., 47-53.

${ }^{24}$ Abū Sayf, 2005, 217-226.

25 Thāmir, 1995, 88-98; cf. al- Yūsufī, 2005, 152-159.

26 Thāmir, 1995, 88-98; cf. al- Yūsufī, 2005, 152-159.

27 Farhān, 2005, 20.

${ }^{28}$ Al-Rawīlī \& al-Bāzighī, 2000, 230.
} 
Frazer's book drove poets to consider the use of myths by convincing them that myth was an effective means of imposing order on common everyday events through the creation of an appropriate poetic and symbolic climate in the poem. Myths, in this view, were considered capable of pushing reason aside and of liberating the imagination from the scientific attitude that became prevalent in modern times. It could do so because it was built on subjective rather than scientific foundations and strove to present a novel perspective that went beyond the reality of social phenomena. It was due to such considerations that Western poets first turned to myth, followed later by their Arab peers. ${ }^{29}$ The book was partially translated into Arabic by Jabrā Ibrāhìm Jabrā and published in the fall of 1984. Its publication had a very significant effect on contemporary Arab poets. ${ }^{30}$

The Golden Bough brought with it a revolution in awareness of myth. It affected contemporary Arab poetry both directly and indirectly. The direct effect came through the Arabic translation, which caused Arab poets such as Badr Shākir al-Sayyāb to begin using myths in their works. But there was an indirect effect as well, by way of Western poets whose poems were influenced by Frazer's work.

The Golden Bough's effect on modernist Arab poets and their use of myth has been studied by Jaroslav Stetkevych. In his Muhammad and the Golden Bough: Reconstructing Arabian Myth he focuses mainly on the theme which Frazer called "death and resurrection",31 as well as other myths that can be found in the poetry of Sa'dī Yūsuf.

\section{The fourth station: Mircea Eliade's Aspects du myth}

Eliade's book Aspects du myth ${ }^{32}$ and its translations into Arabic also contributed to the awareness of Arab intellectuals, including the Iraq poet Sa'dī Yūsuf, of ancient mythologies, despite the relatively long time that passed between the publication of The Golden Bough and Eliade's book. ${ }^{33}$ Eliade in his study argues that myth is sacred history. It tells of the origins and beginnings, of the time when God created the universe and all that is in it. However, he cautions that myth does not deal with origins from a descriptive and intellectual perspective; rather, it constantly strives to evoke the "sacred times" and implant them in the present, for the sake of life in a pure, renewed world. Eliade also discusses the history of myth's influence on human culture down to our day and age. He notes that myth constitutes a realistic expression of ancient human culture and shows how the men of antiquity interacted with their environment.

\section{The fifth station: Roland Barthes' Mythologies}

Roland Barthes called for "mythological criticism", as can be clearly seen in his Mythologies, ${ }^{34}$ where he argues that as long as language and writing dominate society, it is necessary to create a Marxist "mythological criticism" of society, one that analyzes the myths that link a society to its past, to its initial movements and cultures.

Mythologies constituted an important landmark in the study of myth, one that promoted the use of myth in Arab and other poetry. In the book Barthes undertakes a semiotic analysis of social habits and tries to demonstrate that they are legacies of mythical thinking. Among these

\footnotetext{
${ }^{29}$ Kittānī, 2003, 398, 406.

30 See Maḥmūd, 2003, 73.

31 See Stetkevych, 2000.

32 Eliade, 1971.

33 See the Arabic translation, Eliade, 1999.

34 See Barthes, 1957.
} 
habits are wine drinking, drinking milk in the morning, and smoking. He notes that societies today adopt numerous modern myths, such as wine drinking in France, which is considered compulsory, and anyone who does not believe in doing this is considered either sick or impotent. Society, he maintains, unconsciously follows myths and delusions. Men do not smoke cigarettes, but rather their images, and women do not adorn themselves in order to regain their youth but in order to acquire an image of youth. The same is true, according to Barthes, of many other social habits and behaviors that can be analyzed semiotically in a similar manner as legacies of myth. ${ }^{35}$ This discussion makes the book a fertile study of mythology.

\section{The sixth station: Northrop Frye's Anatomy of Criticism}

Northrop Frye is considered a leader in the field of what has come to be known as "archetypal criticism", especially thanks to his book Anatomy of Criticism. ${ }^{36}$ The Canadian critic has received more attention in the Arab world than almost any other Western critic, thanks to several translations of his afore-mentioned book. The book was translated in its entirety by Muhyī al-Dīn Șubhī and also by Muhammad 'Ușfūr. Both translations were published in 1991, by different publishers, the former by the Tripoli (Libya) and Tunis branches of al-Dār al'arabiyya lil-kitāb and the latter by the Jordanian University in Amman. Partial translations were also made, among them one entitled Nazariyyat al-asātiri fí al-naqd al-adabī (Myth Theory in Literary Criticism), translated by the Syrian critic Hannā 'Abbūd and published in 1987 in Homs by Dār al-ma'ärif. Other partial translations have been published in various parts of the Arab world. ${ }^{37}$

Arab intellectuals' and critics' interest in Frye has not been restricted to translations of his work. Many Arab critics, including Hannā 'Abbūd, Muhyī al-Dīn Șubhī, Muhammad Shāhīn, Rītā 'Awậ and Sulaymān Husayn, have adopted his ideas. In fact, it may be said that there exists a contemporary Arab school of literary criticism that has used Frye's approach in its critical writings. Arab interest in Frye, it should be noted, began relatively late. Anatomy of Criticism was first published in 1947 and the two complete Arabic translations appeared only four decades later. ${ }^{38}$

Frye's approach, which has become known as "archetypal criticism", is derived from the psychological theories of Karl Jung, for whom literature was a store of many archetypes kept in the collective memory of mankind, including the myth. Frye's book is important especially for its encyclopedic classification of Anglo-American literature, and Western literature in general, in the context of the afore-mentioned theory of "archetypal criticism. ${ }^{39}$ This helps explain the book's influence on the use of myth by Arab poets, although it must also be remembered that the latter used myth already before the book's publication.

\section{References}

'Abd al-Hayy, Muhammad (2008). Al-Nașș al-kāmil li-qașīdat al-arḍ al-kharāb, no place of publication or publisher. Abū Sayf, Sāndī Sālim (2005). Qaḍāyā al-naqd wal-ḥadātha. Beirut: al-Mu’assasa al-‘arabiyya lil-dirāsāt wal-nashr. 'Awạ̣, Rītā (1987). Usțūrat al-mawt wal-inbi'āth fī al-shi'r al-‘arabī al-ḥadīth.

Barthes, Roland (1957). Mythologies. Paris.

\footnotetext{
35 For a comprehensive presentation see Barthes, 1957.

36 Frye, 1957; see also Humr al-`Ayn, 1996, 33.

37 Humr al-`Ayn, 1996, 33.

38 'Abbūd, 2008, 1-3.

${ }^{39}$ See Frye, 1957.
} 
Būwārdī, Yāsīliyūs (1998). Bayna al-ṣaḥrā’ wal-baḥr. Unpublished MA thesis, Haifa University.

Idem (2003). Majallat Shi'r wal-hadātha al-shi'riyya, unpublished Ph.D. thesis, Haifa University.

Eliade, Mircea (1971). Aspects du myth. Paris: Gallimard.

Eliot, T.S. (1920). The Sacred Wood and Major Early Essays.

Idem (1963). Selected Prose. London.

Farhān, Kāmil (2005). Al-Shi`r wal-dīn: Fāeciliyyat al-ramz al-dīnī al-muqaddas fī al-shi`r al-`arabī. Beirut: Dār alhadātha.

Frye, Northrop (1957). Anatomy of Criticism.

Al-Gharfī, Ḥasan (1987). Harā’iq al-shír. Baghdad: Manshūrāt maktabat al-taḥīr.

Ḥallāwī, Yūsuf (1997). Al-Mu’aththirāt al-ajnabiyya fī al-shi'r al-'arabī al-mu'āṣir. Beirut: Dār al-qalam.

Humr al-`Ayn, Khayra (1990). Jadal al-hadātha fĩ naqd al-shi'r al-`arabī. No place of publication: Arab Writers’ Union.

Jabrā, Ibrāhīm Jabrā (1995). “Min al-marja'iyya al-gharbiyya ilā al-marja iyya al-‘arabiyya, al-usțūra wataḥawwulātuhā fī al-qașīda al-‘arabiyya al-mu'āșira”, al-Mu’aththirāt al-ajnabiyya fí al-shi'r al- ‘arabī al-mu āṣira, 47-55.

Kattānī, Yāsīn (2003). “al-Ḥadātha fī al-fikr wal-adab”, Jāmica 7, 397-412.

Khalīl, Ibrāhīm (2003). Madkhal li-dirāsat al-shi'r al-‘arabī al-ḥadīth. Amman: Dār al-sīra.

Khūrī, Jeries (2004). al-Maṣādir al-sha biyya lil-shi'r al-`arabī al-ḥadīth. Unpublished Ph.D. thesis, Tel-Aviv University.

Levenson, Michael (1986). A Genealogy of Modernism: A Study of English Literary Doctrine 1908-1922.

Lu'lu’a, 'Abd al-Wāḥid (1980). Al-Arḍ yabāb, al-shā'ir wal-qaṣīda. Beirut: al-Mu’assasa al-`arabiyya lil-dirāsāt walnashr.

Maḥmūd, 'Abd al-Raḥmān 'Abd al-Salām (2003). Falsafat al-mawt wal-mīlād: Dirāsa fĩ shi'r al-Sayyāb.

Moreh, Shmuel (1976). Modern Arabic Literature 1800-1970. Leiden: Brill.

Al-Rawīlī, Megan \& al-Bāzighī, Sa`d (2000). Dalīl al-nāqid al-adabī. Casablanca: al-Markaz al-thaqāfī al-`arabī. Sa‘āda, Anțūn (1940). Al-Ṣirāc al-fikrī fĩ al-adab al-sūrī. Beirut: no publisher.

Shāhīn, Muḥammad (1996). Al-Adab wal-usțūra. Beirut: al-Mu’assasa al-‘arabiyya lil-dirāsāt wal-nashr.

Al-Sham`a, Khaldūn (2002). “Taqniyyat al-qināc, dalālāt al-ḥuḍūr wal-ghiyāb”, Fuṣūl 60, 73-85.

Stetkevych, Jaroslav Muhammad and the Golden Bough: Reconstructing Arabian Myth

Thāmir, Fāḍil (1995). "al-Ramz al-usțūrī wal-qināc fī al-shicr al-‘arabī al-ḥadīth, tahawwulāt al-ramz al-shi'rī cind al-Bayyātī, 'ā'isha bayn al-ramz wal-qinā'”, al-Mu'aththirāt al-ajnabiyya fí al-shi'r al-'arabī al-mu 'āṣir, 77-104.

Al-Yūsufī, Muḥammad Luțfī (2005). Kitāb al-matāhāt wal-talāshī fĩ al-naqd wal-shír. Beirut: al-Mu’assasa al'arabiyya lil-dirāsāt wal-nashr. 